\title{
HISTORICAL ANALYSIS AND NOTES ON THE EMERGENCE OF THE PROFESSION OF MOUNTAIN GUIDE AND ALPINISM
}

\author{
T. Dimitrov* \\ Department of Sport, Sofia University, St. Kliment Ohridski”, Sofia, Bulgaria
}

\begin{abstract}
In its essence, a man is a discoverer and researcher. His irresistible desire for knowledge gives birth to progress, and he the thirst to master the secrets of nature. The process of conquering the mountains is long and continuous. A major stage in the development of alpinism was the climbing of Mont Blanc in 1776 by the physician Michelle-Gabriel Pacar and the mountain shepherd and crystal collector Jacques Balma, who was also his guide during the climbing. With this significant climbing, only one stage of exploring the mountains ends. The importance of mountain guides, being professionals, for the development of alpinism, driven by the desires of their clients and scientific and educational purpose is huge. They lay the foundations of modern techniques and methods in alpinism, and create functional equipment for mountain climbing.
\end{abstract}

Key words: guides, climbing methods, development of mountain sports.

\section{INTRODUCTION}

Alpinism, as a conscious and purposeful activity of modern man, generated by interest and love for the mountains is a relatively new phenomenon in human society, but the conquest of the mountains out of necessity can be attributed to prehistoric times. The first discoverer of the mountains is the primitive man who hunted and sought refuge in the mountains. The next groups to explore the mountains were the military and shepherds, who invented the first tools, cats and ghettos to facilitate their movement in the mountains. The need to maintain connections between mountain villages forces their inhabitants to use shortcuts through mountain ranges and passes. The first associations of maroon guides appeared in the settlements under the alpine passes around the 11th-13th century (Big and Small San Bernard, Saint-Gotthard, etc.) (1). In the generations before they united and worked only in this profession of a mountain guide, mountaineers were highland shepherds, crystal seekers, hunters or military.

\footnotetext{
*Correspondence to: Tihomir Dimitrov, Department of sport, Sofia University, St. Kliment Ohridski”, Bulgaria, Team sports and mountain sports, Sofia University, Address: bul. "Tsar Osvoboditel" 15, 1504 Sofia, Bulgaria, e-mail: tisho_9a@abv.bg, mobile: 0889740872
}

\section{METHODS}

Hypothesis - Thanks to mountain guides, have any of the most significant climbs and peaks in the world been climbed and do they make a significant contribution to the development of alpinism and mountaineering in the world?

Purpose - Our purpose is to determine the stages in the development of alpinism, the iconic achievements and the emergence of the profession of mountain guide. Do the stages in alpinism and mountain guides have a connection with each other and what is it?

\section{Tasks}

1. Research of the literature sources on this problem.

2. To determine the main stages in the development of alpinism and their relationship with mountain guides.

3. To follow how and why the equipment for mountaineering and alpinism develops.

\section{Methods}

We used a method of research and historical analysis of documentary and literary sources of alpine climbs and those for the emergence of the profession of mountain guide in the world. 


\section{DIMITROV T.}

\section{RESULTS}

The literature review establishes the periods and stages in the development of mountaineering and alpinism. Following these stages we will clarify the connection between the development of alpinism and professional mountain guides. In different historical epochs, different factors determine a person's attitude to the mountain and he conquers it with different motives and in different forms. However, his victories over the mountain peaks are always a celebration for the human spirit in the fight against the forces of nature. The development of mountain conquest and mountaineering goes through several characteristic historical stages. In the first stage, mainly the practical needs of life and partly religion give rise to man's connection with the mountain. In the second stage, he began to show scientific and cultural interest in it, and mountaineering took its first steps in the service of science. In the third stage, alpinism is born, and its pioneers climb iconic peaks in the Alps and other mountains around the world. In the fourth stage, alpinism reaches maturity and embarks on the path of sports development (2). In the fifth stage, technique, sports training and equipment are increasingly entering alpinism. The training methods provide and develop in detail the motor qualities of mountaineers (climbers and guides) and this is the basis for climbing the most difficult mountains, peaks and rock walls on earth.

Table 1. Illustrates the stages in the development of alpinism and those of guides and mountaineers. Due to the great factology, the table presents only some of the most significant mountain climbs, which are significant in alpinism.

\begin{tabular}{|c|c|}
\hline $\begin{array}{c}\text { Important stages and significant climbs in } \\
\text { alpinism }\end{array}$ & Climbs made with mountain guides \\
\hline $\begin{array}{l}\text { Climbs by nobles and kings in Europe and Asia } \\
\text { for pilgrimage and educational purposes until the } \\
\text { Renaissance. }\end{array}$ & $\begin{array}{l}321 \text { BC Crossing mountain passes from } 3500- \\
4000 \mathrm{~m} \text { above sea level. } \\
11 \text { th - 13th century first associations and } \\
\text { transitions through the high mountain passes Big } \\
\text { and Small San Bernat and San Gotar with guides. }\end{array}$ \\
\hline $\begin{array}{l}\text { Climbs during the Renaissance by humanists, } \\
\text { physicists, poets, doctors, botanists, topographers } \\
\text { and the military. In } 1519 \text { it was climbed in } \\
\text { Mexico by the } 5452 \mathrm{~m} \text { high Popocatepetl volcano } \\
\text { by the conquistadors of Cortez. }\end{array}$ & $\begin{array}{l}\text { In the 16th - 17th centuries there were hikes with } \\
\text { the so-called Grand Tour of the bourgeoisie and } \\
\text { aristocracy, as well as botanical tours in the } \\
\text { Tatras, which were carried out by professional } \\
\text { guides. }\end{array}$ \\
\hline $\begin{array}{l}\text { The birth of alpinism is associated with the ascent } \\
\text { of Mont Blanc } 4810 \text { m high in } 1786 \text {. In } 1855 \text { the } \\
\text { first ascent of Mont Blanc without guides on a } \\
\text { new path was made by the British! In } 1865 \text { the } \\
\text { Matterhorn was climbed, ending the exploration } \\
\text { period of the great peaks in the Alps (3). }\end{array}$ & $\begin{array}{l}\text { The climbing of Mont Blanc was made by a } \\
\text { doctor and a guide (a person who knew the way } \\
\text { and received money for this service). By } 1850 \text {, } \\
\text { Mont Blanc had been climbed } 37 \text { times with only } \\
\text { guides, after which climbs became more frequent } \\
\text { due to the "boom" of mountain tourism. } \\
\text { The first ascent of the Matterhorn was initiated by } \\
\text { E. Wimper (aristocrat and artist), and the group } \\
\text { included the famous leader from Chamonix - } \\
\text { Michel Crowe and the leaders from Zermatt, } \\
\text { father and son Tarauwalder. }\end{array}$ \\
\hline $\begin{array}{l}\text { The next stage in the development of alpinism is } \\
\text { the conscious choice of more difficult paths to } \\
\text { already climbed peaks. The beginning of sport } \\
\text { alpinism. In } 1865 \text { a ascent of Mont Blanc from } \\
\text { the south was made for this purpose. At this } \\
\text { stage, after climbing the main peaks in the Alps, } \\
\text { vertical rock walls and peaks consisting entirely } \\
\text { of vertical access begin to climb. Famous is the } \\
\text { ascent of Dan De Jean, } 4013 \mathrm{~m} \text { high in } 1882 \text {, } \\
\text { considered impregnable. The wedge technique is } \\
\text { purposefully applied to it. } \\
\text { In } 1860 \text { the first } 7,000 \text {-meter peak of Shila, } 7052\end{array}$ & $\begin{array}{l}\text { During the sport ascent on a deliberately chosen } \\
\text { difficult road to Mont Blanc, four Englishmen } \\
\text { took part, led by two Swiss guides. Only one } \\
\text { leader had a primitive pickle, all were without } \\
\text { special shoe equipment! } \\
\text { The first ascent of Dan De Jean } 4013 \text { m was made } \\
\text { by Italians led by the guide Makianitz. It is } \\
\text { equipped with a rope, primitive metal wedges and } \\
\text { a hammer to pave the way to the top! They also } \\
\text { use a wooden beam with sticks driven into it, like } \\
\text { a ladder. } \\
\text { The first and only over } 7000 \text { meters climbs a local }\end{array}$ \\
\hline
\end{tabular}


$\mathrm{m}$ high, was climbed in the Zanskar region. The expedition was organized by British topographers.

In 1912/13 H. Dülfer made a number of difficult ascents and discovered new ways and techniques for insurance and self-insurance.

After the October Revolution, alpinism began to develop in the Soviet Union - initially mainly in the Caucasus, and their school was distinguished by friendly assistance and care for the person. Their climbers are alien to qualities such as individualism and record-breaking. They do not play a significant role in difficult climbs and equipment development. Alpinism developed under the direct care of the authorities in the USSR.

In 1931, brothers Franz and Tony Schmid climbed the north face of the Matterhorn. They have been awarded Olympic gold medals! In 1933, the northern wall of Chima Grande (one of the 6 great northern walls of the Alps) was climbed by Emilio Comici and the Dimai brothers, also guides. He climbs a number of difficult routes to this day.

In 1936, P. Allen and R. Leininger climbed the north wall of Petit Drew, using many wedges (only for securing), but did not use the technique of "artificial climbing".

In 1937 the northern wall of Badile Peak was climbed by Cassin and 4 other climbers.

In July 1938, the northern wall of the Eiger was climbed by two German and two Austrian climbers.

In August 1938, the last "great" wall was climbed, that of Gran Joras by R. Cassin and two other Italian climbers.

The development of technique and mastery in alpinism on increasingly difficult roads to the peaks reaches a new dimension with the climbs of Walter Bonati - mountain guide. In 1951, he climbed the completely vertical and in some places overhanging 400 meters southeast wall of Gran Kapyusen Peak, together with Guido. In 1955 he climbed the western wall of Petit Drew on a new route, and in the winter of 1965 he made a new route on the northern wall of the Matterhorn!

In 1963, the northern wall of the Eiger was climbed "solo" for the first time! connoisseur of the mountains, who is part of the expedition. His name remains unknown to science and it is not clear if he was their guide, but he apparently had experience in mountainous terrain.

In 1910, the guide from Zillertal, Hans Fichtl, made a new type of wedges (the wedges we know today), and Otto Herzog made the first carabineers. Fichtl has a talented student - Hans Dulfer, who became a climbing legend.

Russian and Soviet climbers follow the already trodden paths in the Caucasus by European climbers and guides. An exception is Vasili Semenovski - a certified mountain guide from the Alps. After returning to his homeland in the 1920s, he persistently passed on his knowledge as an instructor and coach to Soviet climbers (4).

Emilio Comici is a leader, a professional guide with over 200 premier climbs in the Alps.

During the period of climbing the most significant northern walls in the Alps in the 30s of the twentieth century, a technique approved by mountain guides was used. It should be noted that some of the climbs were made by guides, and in order to make the other climbs they participated in the study of the way to reach the peaks.

Walter Bonatti is not only a genius climber but also a mountain guide. He made a number of difficult and "impossible" climbs and helped the development of alpinism. During his career as a climber, he can be said to achieve everything, and the entry of climbing with "not clean" means deprives him of alpinism.

The wall of Eiger was climbed by the Swiss guide Darbele with a bivouac. 


\begin{abstract}
Alpine alpinism and conquest of the high mountains around the world

In the first half of the 20th century, the first expeditions to explore and climb the highest mountains and peaks on earth - the eightthousand meters - began to be organized. Attempts are being made to succeed, but it is not yet available. In the middle of the century, from 1950 to 1964, all the highest peaks were climbed. In 1950 the first peak over eight thousand meters was climbed - Annapurna 8091 meters high by a French expedition!
\end{abstract}

In 1953, Mount Everest was climbed $8848 \mathrm{~m}$ - the highest on the planet by E. Hillary and T. Norgay. Sherpa was invited on an equal footing with the British, as a climber not only as a porter and guide.

The second highest peak on the ground was climbed - K2 $8611 \mathrm{~m}$ high in 1954 by an Italian expedition.

The last stage in the development of alpinism. After the second half of the twentieth century, companies involved in the production of equipment began to pay salaries to climbers and climbers, as well as some countries. They become professionals, just like mountain guides. Their competition is fierce and athletes begin to prove their skills by making increasingly difficult climbs, often without any insurance. They cross the boundaries of fear and common sense, starting to make fast, difficult and unsafe climbs on their own! When they make a mistake, they pay the highest price. The equipment and motor skills develop at a brisk pace. New materials for clothing have been invented - membranes that allow the body to "breathe". The shoes are warmer and lighter; their soles are made of special rubber according to their purpose. They create clothes from warm fabrics with great ease and quick drying. Ropes and carabineers are becoming stronger and lighter. Temporary movable means of securing and new devices for securing and working with rope have been invented.
The first successful expedition to a peak with a height of over 8000 meters was the French and was composed mainly of guides. Maurice Erzog and L. Lashnal, a mountain guide and teacher at the National School of Mountain Guides in Chamonix, reached the top. Another leader, Gaston Rebuff, played a role in the success of the expedition.

A fateful date in mountaineering is climbing Mount Everest. It should be noted that Tensing Norgay has participated in six previous expeditions, reaching an altitude of about 8600 meters above sea level and he knew the way very well. He was invited to the English expedition and received money for it, climbed to the top with $\mathrm{E}$. Hillary.

The expedition is Italian and consists mainly of mountain guides with vast experience in the Alps and other high mountains around the world. Lino Lachidelli and Achilles Compagnoni climb to the top, and the last camp built by V. Bonati is crucial for their success - they are all leaders!

Mountain guides are consultants to equipment companies. The most prominent of them receive salaries from companies and sponsors. They made a number of significant ascents, of which in 1968 Reinhold Messner climbed for the first time a route over 6 categories of difficulty (considered today as 8-th category) (5). He climbed Everest for the first time in 1979 without the use of supplemental oxygen, and also climbs all the peaks above 8,000 meters. Messner quit his job as a guide and became a professional athlete and public figure. There are many achievements of the guides for the development of the equipment and the difficult ascents. Not to mention the Swiss guide Danny Arnold, who climbs the northern walls of: The Matterhorn in one hour and forty-six minutes, the northern wall of Gran Joras in two hours and seven minutes, Chima Grande in 46 minutes, Eiger in two hours and twenty and eight minutes, etc.!

Guides from all over the world set records in alpinism, making a number of climbs in the high mountains. In 2004, Pemba Dorje Sherpa climbed Everest from base camp to the summit in 8 hours and 10 minutes. He has several climbs to the top and works as a guide. Another record also belongs to the leader - in 2019 Kami Rita Sherpa climbed Everest for the 24th time! 
After the literature research and analysis on this issue, the five main stages related to the development of alpinism, mountaineering and the conquest of the plans were identified. The need for mountain guides and their appearance is established in the second stage of the conquest of the mountains. Then they appeared in the first associations in the Alps under the passes of Big and Small San Bernard and Gothar, and in 1822 in Chamonix. Significant is the ascent of Mont Blanc in 1776 by the doctor Michel-Gabriel Paccar and Jacques Balma - the mountain shepherd collector of crystals, who knows the way to the top from previous experiments. The following year, in 1777, Professor Saussure climbed with 18 guides - a real caravan, which set off on July 31 from Chamonix. They are again led by Balma, the peak was reached after two bivouacs on August 2, making another bivouac on the descent. Saussure as a physicist manages to make all the measurements he has dreamed of for 25 years, by the way measuring the height of the peak, for this purpose he carries 3 barometers! This expedition gives the beginning and appearance of a new type of tourism. After climbing the peak of the Alps, the climbs of the other main peaks in the mountain begin. They are made by wealthy clients who are guided and cared for by local guides. This is done with one or more bivouacs in the mountains, the guides pave the road, dig steps and help their customers in difficult passages. The leaders at the time also worked with people on the Grand Tour, considered almost a must-see for young English aristocrats before embarking on their own journey in society. Perhaps the beginning of today's tourism began in the 16th-17th centuries, gaining particular popularity in the mid-18th century. A must stop is Geneva, then cross the Alps and continue to Italy. Like the British, he was joined by aristocrats from other European countries, as well as the flourishing bourgeoisie at the time. The emergence of modern mountain guides - those who lead people interested in the mountains because of their beauty, driven by scientific interests or simply for sporting success, is in the XVIII century. The new "mountain tourism" is rapidly gaining momentum, and in addition to the Chamonix Valley, the Mont Blanc region and other valleys and peaks in the Alps attract wealthy tourists. Several regions are being formed in the Alps, where there is a demand for the services of mountain guides -
Chamonix, Courmayeur, Zermatt, Grindenwald. Of course, only a small part of the tourists climbed the high icy peaks, most were content to climb to a place with a beautiful view, often on the back of a horse or mule. The improvement of the paths dates back to the beginning of the 19th century, mainly those leading to the approaches to the high peaks. A new tourism industry is starting. This type of tourism is also developing in the Pyrenees, and it is based on the visitors of the balneological centers that became famous at the end of the 18th century. The hot mineral springs began to attract many visitors to the resorts and towns located below the mountain peaks. Considering the clientele, in addition to the classic walking tours and climbs, there were also horseback riding and even a stretcher carried by porters. Equipment of the first guides and climbers are: the long pickle, the alpenstock for the clients, the shod shoes and the hemp ropes, which will remain unchanged for more than 100 years from the first climbs! The period between the memorable ascent of the Weterhorn by Alfred Wills in 1854 and the Matterhorn by Edward Wimper in 1865 is worth a little more time. Called in some places the golden period of that glorious era, in which the profession of a driver is now official, and alpinism is taking shape as a sport. Wealthy English (mainly) customers climb with their guides. During this period the first climbs of almost all peaks in the Alps were made. 1865 was the culmination of the "Golden Years of Alpinism", the year with the most premieres, of which the Matterhorn climb, and this year there are over 50 premiere climbs.

The history of the establishment of the professional association of guides in Chamonix dates back to 1822 , when the first regulations were drawn up. How to become a leader in the beginning - leaders' associations were closed communities, only local people were members? The skills of the guide were passed from father to son or family related and were not subject to verification upon receipt of the title of guide. A commission of respected old leaders and the chairman of the association conduct an exam. The candidate had to have a certain length of service as a porter or assistant and to have made some climbs as such (he presented to the committee a list of his climbs). The leaders he worked with had to make recommendations for him. The candidate was asked questions about the climbs he had made, as well as other routes and climbs in the area 
that he should know. The exam was geographical - trails, approaches and routes to the peaks, altitudes, landmarks on the routes that the driver must be able to show customers. The commission assessed whether he deserved to be admitted to the association.

With the development of mountain tourism, the first associations of climbers appeared. The first to set an example is the English Alpine Club in London, founded in 1857.

Once the high alpine peaks have been climbed, the hiking travelers look to the other, more distant mountains. It is natural for them to take with them their guides from the Alps, with whom they made their first steps in the mountains. The guides are hired by researchers, geographers, scientists, as well as climbers with a purely sports orientation. They make premiere climbs in the Caucasus, South America, Africa, New Zealand, as well as the first Himalayan expeditions. The leaders of these expeditions are mainly from Switzerland, France and Italy.

\section{CONCLUSION}

From the literature study of the historical sources and analysis of the sign climbs in the mountains of the world, the stages in the development of alpinism and mountaineering are distinguished. It is established that mountain guides have a leading role in the development of alpinism and exploring the massifs around the world. Thanks to them, part of the climbing technique and the equipment for mountaineering and alpinism are improved. Due to the need of guides for more functional equipment and being consultants to manufacturing companies, they contribute significantly to the development of this industry.

\section{REFERENCES}

1. Popjordanov, L. at all, The mountains up close. Odiseya-In,Sofia, ISBN 978-95492206-4-3, pp 15, 2012.

2. Repnenski, G., Conquest of the mountains. Medicine and physical education, Sofia, pp 10 - 14, 1968.

3. Beshev, S., Peaks. Zombori, Plovdiv, pp 8, 2004.

4. www.risk.ru

5. Kalvi, L., Filipini, S., Killing the impossible. Book addiction, Sofia, ISBN 978-619-195-210-6, pp 78-80, 2019. 